\title{
Japan's Changing Defense Posture and Security Relations in East Asia
}

\author{
Andrew R. Capistrano and Shuhei Kurizaki
}

Japan's Diet passed new defense legislation in 2015. It reinterprets the constitutional clause renouncing the threat or use of force (except to repel an attack on Japan) to allow collective self-defense and permit expanded roles for the Japanese Self-Defense Forces. The government presents these changes as consistent with Japan's traditional postwar defense posture, vital to support allied deterrence of threats against Japan, and necessary to enhance Japan's security in a region of shifting power. This article disputes these claims. Rather, the new laws (1) signal a strategic shift away from the Yoshida Doctrine by reinterpreting the constitution, (2) fail to generate new U.S. commitments or strengthen preexisting ones that enhance Japan's security, and (3) risk exacerbating the Sino-Japanese security dilemma. This is because the changes are occurring alongside the Senkaku Islands dispute, which raises strategic mistrust, and they revise the alliance to give Japan a greater role in regional security, which China has historically seen as a future threat. When taken together, these under appreciated effects of the new laws may help the alliance endure and let Japan support the regional status quo in the long term, but will likely decrease Japanese security in the short term by prompting a defensive Chinese response. We show how the recent history of East Asia's security dilemma and IR theory both cast doubt on the ability of the new laws to generate security for Japan.

Key Words: Japan, collective self-defense, deterrence, reassurance, security dilemma, U.S.-Japan alliance, Sino-Japanese relations, Yoshida Doctrine

$\mathrm{J}$

apan's defense posture is in flux. The cluster of bills passed by the Upper House of the Diet in September 2015 allows for collective self-defense (CSD) and expands the permissible roles for the Japanese Self-Defense Forces (SDF) in

*Andrew R. Capistrano(capistrano@fuji.waseda.jp) received his M.A. from the Graduate School of Political Science at Waseda University and a B.A. in history from the University of California, Berkeley. He is currently a research assistant at the Rebuild Japan Initiative Foundation, a Tokyo think tank. This article does not reflect the views of the Foundation.

**Shuhei Kurizaki(kurizaki@waseda.jp) is Associate Professor at the School of Political Science and Economics at Waseda University. Prior to his current position, he was Assistant Professor of Political Science at Texas A\&M University and Pre-Doctoral Fellow in National Security at Harvard University's John M. Olin Institute for Strategic Studies. He received his Ph.D. from the University of California, Los Angeles. 
East Asia. The administration of Prime Minister Shinzo Abe argues that this shift will help Japanese national security and protect the status quo, regional norms, and the postwar liberal order. Domestically, the debate surrounding the new legislation has been heated and has prompted public demonstrations. Many of the dissenters were motivated by the perceived unconstitutionality of the new laws, which reinterpret the self-defense clause in the Japanese postwar constitution. Others were concerned that Japan could be dragged into a U.S.-led war in the Middle East after relaxing the constitutional constraint on the use of force, or that Abe was setting the stage for fully normalizing Japan's military.

These debates are far from settled. However, we believe that they overlook a more fundamental and important question: do the new laws enhance Japan's security, and if so, how? This article addresses whether Japan's new defense posture might inadvertently foster insecurity. In contrast to government claims, the ramifications of the new laws are unlikely to be solely beneficial and may lead to a net decrease in security. This is because CSD and new roles for the SDF are intended by the Abe Administration to signal resolve while at the same time retaining the ability to reassure Japan's neighbors. Reassurance has been fundamental to postwar Japanese defense strategy, and it appears that the new laws try to preserve this key function while enlarging the scope of permissible defense operations.

We argue that it will be difficult for Japan in the current strategic environment to accomplish both these aims. The vagueness of the new laws may heighten other states' uncertainty about where in the region and under what circumstances future Japanese policymakers would - or could - opt to invoke the new powers. Moreover, the reinterpretation is less a policy shift as much as a strategic shift away from the Yoshida Doctrine's use of the constitution as a reassurance mechanism. Actual deviations from the trend of Japanese foreign policy seem unlikely. As a new legal framework to strengthen the U.S.-Japan Alliance, they don't bind Japan with a blanket commitment to come to America's defense, so their ability enhance deterrence will likely be circumscribed. Rather, combining uncertainty, a strategic shift, and a strengthened defensive alliance may have unintended consequences for the security dilemma.

In fact, strategic mistrust in the East China Sea may be intensified by Japan's future role in regional defense, potentially prompting a Chinese response that would decrease Japan's security. The rise of China has brought security issues into greater prominence for post-Cold War Japanese foreign policy. But in the past, Sino-Japanese security dilemma dynamics have been exacerbated by two additional factors: mutual strategic mistrust, and Japan's gradually evolving role in the U.S.-Japan Alliance. We argue that the new legislation, albeit designed to defend the status quo amid a changing power balance, signals a clear shift in 
Japan's postwar strategy that will heighten mistrust. In addition, the new laws allow Japan to take on a bigger role in the alliance, the future nature of which is undetermined. The under-appreciated consequences of these effects on security dilemma dynamics in the region could be dramatic.

The Abe government claims that Japan has not undergone a strategic shift at all. They note that the recent changes follow a familiar post-Cold War trajectory, and it's true that the U.S.-Japan Alliance has long adjusted to new regional challenges. But from the Chinese perspective, the alliance has historically been seen as either a 'bottle cap' restraining Japan's latent desire to normalize its defense posture, or an 'eggshell,' with the U.S. as a hen incubating the resurgence of Japanese military power (Liu 1998; Christensen 1999). We argue that CSD opens the bottle cap of restraint embodied in the Yoshida Doctrine and made possible by one-sided U.S. defense guarantees. Additionally, new roles for the SDF will crack the eggshell by reducing the historical asymmetry of the alliance and opening the door for Japan to support the status quo militarily in East Asia. China is particularly sensitive to Japan's greater security responsibilities in the region because these are arising alongside intense territorial disputes. Although in the long term the alliance may become more cohesive, and a more symmetrical relationship may serve as an accepted bedrock of the regional order, the changes are likely to reduce Japan's short-term security in ways the government and the protesters have not satisfactorily addressed.

This article proceeds as follows. Section 1 surveys the new laws, Japan's postwar strategy, and Abe's statements. In section 2, we argue that the legislation undercuts the foundation of the Yoshida Doctrine by reducing the reassurance function of Article 9, the so-called self-defense clause in the Japanese constitution. As this was instrumental in supporting the postwar order, the recent strategic shift is more pronounced than any immediate policy changes currently indicate. In section 3, we briefly argue that the IR literature questions the casual logic of Abe's claim that making the alliance more symmetric will in and of itself enhance deterrence and thus enhance Japan's security. In fact, the effect of the new laws will be to enhance allied cohesion. This can help the alliance endure and integrate Japan deeper into the U.S.-led regional security architecture, but it may further undermine allied assurances that it is not intended as an instrument to contain China. Finally, section 4 surveys the security dilemma in East Asia and shows how the Senkaku/Diaoyu Islands dispute has increased strategic mistrust. In part, the new laws are a security-seeking response to Chinese assertiveness in this crisis. We also survey China's (mis)perceptions of the U.S.-Japan Alliance and show how past changes to the alliance guidelines that expanded Japan's regional security role have inadvertently signaled revisionist intentions. 


\section{THE NEW LEGISLATION AND JAPAN'S POSTWAR STRATEGY}

In September 2015, the Diet passed legislation revising existing laws and adding new contingencies in which the SDF can legally operate under Article 9. The longstanding official interpretation of Article 9 placed restrictions on SDF operations that prevented them from assisting the U.S. in a military conflict or directly participating in any operations unless Japan was under attack. This clause underpinned Japanese postwar strategy. The reinterpretation allows two changes that depart from this traditional posture: the new laws expand the scope of permissible military actions to include contingencies when Japan is not under direct attack, and they revise the conditions regulating when the SDF can provide operational support outside of Japanese sovereign territory. ${ }^{1}$

\section{BACKGROUND TO THE LEGISLATION AND TWO MAJOR CHANGES}

The new laws originated in a Prime Minister's Decision taken in April 2007 during the first Abe Administration. A high-level panel was convened and tasked with exploring the legal issues surrounding the right of CSD under the traditional postwar interpretation of Japan's constitution, particularly in the context of certain scenarios the Abe Administration saw as likely challenges for Japan's defense amidst a shifting security environment. The panel argued that previous attempts to enhance security had inappropriately tried to expand the issues that could be covered under 'self-defense' to include joint operations with the U.S. or peacekeeping. They therefore recommended that these contingencies be correctly covered under a justifiable right of CSD, requiring a change in official constitutional interpretation and Diet approval. ${ }^{2}$

Abe resumed the panel, which had been dormant while the Liberal Democratic Party (LDP) was out of power, shortly after he became Prime Minister for the second time in December 2012. Unlike in 2007, when the panel had been limited to exploring scenarios that Article 9 did not unambiguously cover, they were now asked to provide legal support for a constitutional interpretation that would cover them. Their 2014 report delivered a new interpretation of Article 9 allowing CSD. 3 In July of that year, a cabinet decision adopted the panel's recommendations and

\footnotetext{
${ }^{1}$ We will refer hereafter to the reinterpretation of the constitution to allow CSD and expanded SDF roles under certain conditions collectively as the "new laws."

${ }^{2}$ See Office of the Prime Minister of Japan, "Report of the Advisory Panel on Reconstruction of the Legal Basis for Security" (June 24, 2008).

${ }^{3}$ See Office of the Prime Minister of Japan, "Report of the Advisory Panel on Reconstruction of the Legal Basis for Security" (May 15, 2014).
} 
put forward an agenda to develop new legislation and revise existing laws. ${ }^{4}$ Two bills were proposed in May 2015 and subsequently passed both houses of the Diet. This article is concerned with the Legislation for Peace and Security, however the International Peace Support Bill, which enhanced the SDF's ability to participate in peacekeeping operations, is a significant shift in its own right. Here we focus on two major changes in the former bill that affect the future potential for Japan's defense posture in East Asia.

First, the legislation reinterprets Article 9 as being more expansive than previously thought, allowing Japan to assert its right to CSD under the U.S.-Japan Alliance or in defense of another state. The longstanding interpretation permitted military action only under three conditions: (1) Japan was under armed attack; (2) the attack could not be repelled by other means; and (3) only the minimum force necessary would be used if the first two conditions were met. The new interpretation amends the first condition to recognize an attack against an ally or a country in a close relationship with Japan as a threat to national security. 5 Interpreting Article 9 this way permits the use of force even if Japan is not directly attacked. The Abe government argues that they put forth this amendment because they recognized that Japan's security environment had been "fundamentally transformed." Due to the regional balance of power "continuously evolving... even an armed attack occurring against a foreign country could actually threaten Japan's survival." 6

Second, the legislation permits the SDF to operate regionally in new ways. Most importantly, the geographical limits for legal deployment of the SDF have been replaced by conditions. The laws strike the ambiguously defined phrase “...situations in areas surrounding Japan" and substitute an arguably more open-ended clause: “...situations that will have an important influence on Japan's peace and security." 7 Within the U.S.-Japan Alliance, these revisions also buttress the 2015

\footnotetext{
${ }^{4}$ See Office of the Prime Minister of Japan, "Cabinet Decision on Development of Seamless Legislation to Ensure Japan's Survival and Protect its People" (July 1, 2014).

5 The phrase added to the first condition is: "...or when an armed attack against a foreign country that is in a close relationship with Japan occurs and as a result threatens Japan's survival and poses a clear danger to fundamentally overturn the people's right to life, liberty, and the pursuit of happiness." See Ministry of Foreign Affairs of Japan, "Japan's Legislation for Peace and Security" (November 2015) and Ministry of Defense of Japan, "Defense of Japan 2015” (white paper, July 2015), II-1-2.

${ }^{6}$ See Ministry of Foreign Affairs of Japan, “Japan's Legislation for Peace and Security” (November 2015) and Ministry of Defense of Japan, "Defense of Japan 2015" (white paper, July 2015), II-1-2.

${ }^{7}$ Ministry of Defense of Japan, “Defense of Japan 2015” (white paper, July 2015), II-1-3. When the three conditions are met, the new security laws allow for three types of missions: rendering logistical support to foreign military forces engaged in a conflict with a third party; accommodating their forces in specific Japanese bases and facilities; and imposing maritime transportation restrictions on
} 
alliance guidelines that acknowledge the potential for SDF cooperation with U.S.led maritime operations to protect the sea lines of communication and freedom of navigation. ${ }^{8}$

These two changes are significant developments in the evolution of postwar Japanese security policy. On the one hand, they alter the traditional Cold Warera defense posture of the alliance by making bilateral commitments slightly more symmetric. On the other hand, and perhaps on a deeper level, the new laws challenge the strategic foundation of the Yoshida Doctrine - the ability of Japan to reassure its neighbors as it pursued economic growth - by altering Japan's potential role in its adversaries' security environment.

\section{REASSURANCE AND DETERRENCE IN JAPAN'S POSTWAR STRATEGY} Shigeru Yoshida was Japan's first postwar Prime Minister under the 1947 U.S.drafted constitution and he is considered the architect of the strategy Japan followed throughout the Cold War. This 'Yoshida Doctrine' strategy rested on three pillars. First, Japan would concentrate on rebuilding its domestic economy and infrastructure; internationally, it would become embedded in the U.S.-led liberal economic order, increase exports to the U.S., and restrict its regional relationships to trade and investment. This order was grounded in free and open maritime trade, and Japan would benefit from U.S.-protected sea-lanes. Japan would use trade and investment to foster good relations, and to support countries with favorable markets for Japanese goods or natural resources regardless of politics.

Second, Japan would rely on the U.S. for national defense in order to provide the security prerequisites for reconstruction. Although Article 9 prohibited the creation of a military, the Korean War and U.S. pressure led to the formation of the SDF's predecessor in 1952. That same year, the Treaty of Mutual Cooperation and Security allowed the U.S. to station forces on Japanese soil, and in 1960 the treaty was amended to form the U.S.-Japan Alliance. Under its terms, the U.S. was obligated to defend Japan from armed attack but Japan had no such reciprocal commitment, and the SDF was to be used only if Japanese territory were directly attacked.

Third, Japan would find its place in the world and expand its influence in the postwar order through international institutions rather than power politics. Keeping a low profile in Cold War regional politics was essential, but the new postwar institutions offered a way for Japan to restore its regional and interna-

\footnotetext{
the third parties.

${ }^{8}$ See Ministry of Foreign Affairs of Japan, "The Guidelines for Japan-U.S. Defense Cooperation" (April 27, 2015).
} 
tional image. To this end Japan entered the GATT in 1955 and the UN in 1956, and has been a major supporter of regional forums. ${ }^{9}$

With these three principles, the Yoshida Doctrine formed the linchpin for the regional security order by reassuring Japan's neighbors as well as Japan itself. As the economy boomed and Japan emerged as an economic powerhouse, it was imperative to mitigate fears of resurgent militarism. In particular, the commitment of successive Japanese administrations to Article 9 signaled self-restraint and consistent adherence to the Yoshida Doctrine made this signal credible. ${ }^{10} \mathrm{By}$ outsourcing security to the U.S., Japan was able to maintain a minimal defense posture and to cap defense spending at less than $1 \%$ of GNP for years. The Cold War U.S.-Japan Alliance also reassured the Japanese government and its people by mitigating domestic fears of the communist threat in Asia. The U.S. obligation to defend Japan under Article 5 of the alliance treaty and the American military presence in Japan under Article 6 offset the security deficit stemming from Japan's constitutionally restricted defense posture. ${ }^{11}$ Reassurance in the Yoshida Doctrine proved to be strategically and economically advantageous. The commitment to a minimal defense posture and unilateral self-restraint could be leveraged to avoid entrapment in America's Asian conflicts, while it simultaneously served as the foundation for Japan's peaceful postwar image that it continues to promote in the international community (Potter 2015).

The U.S.-Japan Alliance also provided a deterrence mechanism critical to Japan's postwar strategy. The asymmetric defense obligations formed the backbone of this strategy by generating credible threats to deter armed attacks. The U.S. stationed troops in Japan and extended its nuclear umbrella over the archipelago to contain communism, signal resolve, and deter aggressors. But like NATO, which also sought to ameliorate the historical distrust between France and West Germany, the alliance provided defense guarantees that reduced the potential for military competition and strategic mistrust. The challenge has been to retain both of these functions as the security environment dramatically changed and the alliance steadily evolved along with it.

\section{THE SHIFTING ROLE OF THE U.S.-JAPAN ALLIANCE}

\section{U.S.-Japan security relations developed from the original 1952 treaty to the 1960}

\footnotetext{
${ }^{9}$ See Hughes (2015b) and Potter (2008).

${ }^{10}$ See Glaser (1997) on the benefits of self-restraint in tempering the security dilemma and Lind (2004) on buck-passing in Japanese foreign policy.

${ }^{11}$ On strategic benefits of the Yoshida Doctrine, see Nilsson-Wright and Fujiwara (2015) and Potter (2015). For the argument and some evidence that the U.S. military presencefunctions as a tripwire for deterrence, see Schelling (1966) and Gartzke and Kagotani (2015).
} 
alliance and the addition of guidelines in 1978. In 1960, Japan was unable to contribute much to the alliance but SDF capabilities developed alongside Japan's rapid economic growth. The initial 1978 guidelines reflected the government's desire to take greater control of its defense policy following U.S. rapprochement with China, one of the infamous 'Nixon Shocks.' They delineated the responsibilities and "division of labor" between the allies, for the first time allowing the SDF to jointly plan and participate in training exercises, as well as engage in operations with U.S. forces. ${ }^{12}$ Jennifer Lind (2004) has argued that this restrained but evolving defense posture is an indication of Japan's buck-passing strategy, which, throughout the postwar era, has "increased its military power and expanded its military roles only when [the U.S.] failed to respond to growing threats." For example, the buildup of the Soviet Pacific Fleet in the late 1970s and the concomitant post-Vietnam drawback of U.S. forces in Asia led Japan to strengthen its capabilities as well as contribute more to the alliance.

After the collapse of the Soviet Union, policymakers on both sides of the Pacific reconsidered the alliance's utility. Japan perceived itself to be more secure in post-Cold War Asia, and the United States wanted a greater role to be played by its increasingly wealthy partner so that U.S. forces could be drawn down as part of the 'peace dividend' (Christensen 2011, 232). The longstanding deterrent purpose for the alliance at the heart of the Yoshida Doctrine appeared to have evaporated, and U.S. policymakers considered the U.S.-Japan Alliance "dangerously vague and out of date" in light of new security concerns emerging in the region (Christensen 1999, 58). Beginning with the 'Nye report' in 1995, Japanese and American policymakers agreed that preserving the alliance's stabilizing role in the region required adjustments, including enhancing Japan's defense posture (Murata 2000, 20-21). In 1997, the original guidelines were revised to allow the SDF to provide rear-area support during bilateral military operations "in areas surrounding Japan," not only in defense of the home islands. ${ }^{13}$

This creeping expansion toward regional security is highlighted in Japan's 2004 National Defense Program Guidelines (NDPG). This document serves as the basis for Japan's strategy and identifies two national objectives: to prevent threats to Japan or, if necessary, repel them; and to improve the international security environment to reduce the chance of threats developing. ${ }^{14}$ The NDPG

\footnotetext{
${ }^{12}$ See Ministry of Defense of Japan, "The Guidelines for Japan-U.S. Defense Cooperation" (November 27, 1978) and Takahashi $(2013,2)$.

${ }^{13}$ See Ministry of Defense of Japan, "The Guidelines for Japan-U.S. Defense Cooperation" (September 23, 1997).

${ }^{14}$ These objectives were to be accomplished by three means: Japan's own actions; cooperation
} 
directed the government to find a common strategic vision for the U.S. and Japan, to clarify the roles, missions, and capabilities that each ally would contribute, and to realign U.S. bases on Japanese territory. ${ }^{15}$ In 2005, the U.S. Secretaries of State and Defense met their Japanese counterparts and agreed to a new policy. Together, they spelled out the areas for cooperation in East Asia to clarify the ambiguities of "areas surrounding Japan" that had been introduced in the 1997 guidelines. ${ }^{16}$ This clarification was not particularly destabilizing in the context of the mid-200os, in part because they kept SDF roles circumscribed. The change was justified as responding to North Korea's nuclear ambitions and allowing Japan to aid America's war on terrorism.

Richard Samuels (2007) shows how Japan has struggled to find loopholes in the legal constraints imposed by the constitution to steadily increase its capabilities, passing 15 defense-related laws between 1991 and 2007 that expanded the role of the Coast Guard and civilian agencies and thereby stretched the limits of Article 9. The 2015 legislation and new alliance guidelines build off of this incremental and decades-long expansion of permissible defense roles. Japan is not charting an altogether new course to 'go it alone' as a regional actor but is responding to U.S. pressure and the strategic environment to contribute more to regional security. In many ways, the recent legislation simply codifies existing changes and provides sounder legal footing for trends that have been developing over the last two decades. As Joseph Nye and Richard Armitage argued in 2007, keeping the alliance frozen in its lopsided Cold War incarnation was impractical and costly for the U.S. in the long term:

What is necessary [for the U.S.]... is not only greater collaboration on security matters, but a recasting of Japan's role and self-perception in such matters. [...] Japan must make the alliance more equal by adequately providing for more of the areas required for its own defense [...] The ongoing debate in Japan on the Constitution is encouraging... the United States would welcome an alliance partner with greater latitude to engage where our shared security interests may be affected (Armitage and Nye 2007, 19-20, 22).

In sum, the Abe government presents the right to CSD as a minor practical

with U.S. forces; and cooperation with the international community. This last aspect was a significant shift in its own right.

${ }^{15}$ See Ministry of Defense of Japan, "National Defense Program Guidelines" (December 10, 2004) and Takahashi $(2013,4)$.

${ }^{16}$ U.S. Department of State, "U.S.-Japan Alliance: Transformation and Realignment for the Future" (October 29, 2005). 
change to mitigate the problems of this slow expansion's shaky legal justification. The new laws seek to build off of the reassuring continuity of the Yoshida Doctrine while enhancing allied deterrence by preserving and only reinterpreting Article 9.

\section{PRIME MINISTER ABE'S ARGUMENT}

The Abe Administration presents the legislation as a defensive response to a fluctuating security environment that is in step with alliance trends - neither a break from the past nor business as usual. He laid out his diplomatic vision in a 2013 speech by declaring, "Japan's national interest lies eternally in keeping Asia's seas unequivocally open, free, and peaceful," and "Though times may change, [Japan's] objectives remain immutable." He identifies these objectives as (1) the U.S.-Japan Alliance and (2) strong ties with maritime Asia through trade and investment. ${ }^{17}$ However, protecting the same, unchanging interests does not necessarily ensure that the means of achieving them will remain permanently effective.

Often, there is significant tension between the traditional way that Abe frames his policies and the changes he promotes. In a major address to the U.S. Congress in April 2015 announcing the new guidelines, he spoke of how the alliance had been foundational for Japan's postwar growth and prosperity. At the same time, he referenced changing the longstanding constitutional interpretation of Article 9 to facilitate greater U.S.-Japan military coordination, thereby generating "credible deterrence for the peace of the region." 18 Other statements reiterate how his initiatives to expand SDF roles are a response to changing security conditions that keep the postwar renunciation of force intact. After releasing the cabinet decision on the new laws, Abe concluded:

Japan has followed the path of a peace-loving nation since the end of WWII [...] However, it was not realized by simply proclaiming the word 'peace.' I strongly believe that it is the fruit of the efforts of our forebears who adapted to the changes in the environment and then turned their wish for peace into action [...] With action comes criticism [...] Nonetheless, our history to date proves that such criticisms were entirely misguided [...] With deep remorse for WWII, we have consistently upheld the 'pledge to never wage war' over the past 70 years [...] Let us be confident. Let us no longer turn a blind eye to the changes in the environment and remain idle. ${ }^{19}$

\footnotetext{
${ }^{17}$ See Office of the Prime Minister of Japan, “The Bounty on the Open Seas: Five New Principles for Japanese Diplomacy" (January 18, 2013).

${ }^{18}$ See Office of the Prime Minister of Japan, "Towards an Alliance of Hope" (April 29, 2015).

${ }^{19}$ See Office of the Prime Minister of Japan, "Press Conference by Prime Minister Shinzo Abe Following the Cabinet Decision on the "Legislation for Peace and Security" (May 14, 2015).
} 
This reiterates typical portrayals of Japanese defense policy made by postwar governments. Abe's use of this traditional framing to announce a major change in defense policy is odd, because after reinterpreting Article 9, we argue that this reassuring signal to the Japanese public and the region now lacks its usual credibility.

\section{THE NEW LAWS AS A STRATEGIC SHIFT HINDERING REASSURANCE}

Japanese defense policy remains, at least for the time being, grounded in a familiar postwar trajectory. However, reinterpreting the expansiveness of the constitutional constraints represents a major shift in Japan's strategy that Abe appears to downplay in his statements. ${ }^{20}$ The increasing severity of the security environment may be a legitimate reason for the new laws. However, they attenuate the reassurance mechanism of Article 9 by replacing a clearly defined constitutional constraint - albeit stretched over decades - with an ambiguous reinterpretation. This section shows how the laws have weakened this mechanism's effectiveness.

\section{THE DEFENSE REFORMS AND}

\section{A DEPARTURE FROM JAPAN'S POSTWAR STRATEGY}

The new laws constitute a major departure for two reasons. First, prior shifts in Japan's defense posture kept the commitment to restraint embodied in Article 9 intact - Japan's military role in the alliance remained restricted to defense of the home islands. In contrast, the new laws plainly and purposefully expand SDF activities and their operational conditions beyond the minimum necessary for home defense. Second, allowing joint support for other countries outside the U.S.-Japan Alliance - whether by direct military intervention or to augment third party military operations - expands the range of issues and geographic space that the alliance can influence. Japan appears to be taking the first steps toward integrating its military capabilities with other U.S. allies and partners in the region. ${ }^{21}$ To allow this, the new laws change clear maximum limits on where and when Japan's defense capabilities can be employed into hazy minimum conditions, often seemingly subjective, that must be met before their deployment.

${ }^{20}$ See Hughes (2004, 64-66) on earlier tensions between the constitution and the need for reevaluating the role of the SDF. As noted earlier, one reason for allowing CSD under the new laws was that the traditional definition was stretched nearly to the breaking point by the 2004 NDPG.

${ }^{21}$ See Hughes (2015b). 
This has at least two strategic consequences. First, on the one hand, it no longer restrains Japan from supporting the U.S. military in situations where Japan is not under direct attack, and therefore Japan can no longer credibly commit to only employing the SDF in defense of the home islands. On the other hand, the traditional interpretation of Article 9 and Japan's commitment to adhere to it despite regional crises kept the nation from becoming entrapped in a Cold War conflict. In the Vietnam War, as in Korean War, Japan resisted U.S. calls to rearm by citing constitutional restrictions. After passing the new laws, Japan will no longer be able to enjoy this constitutional safeguard against the risk of entrapment should a militarized dispute involving the U.S. occur in the region.

Second, the new interpretation undermines preexisting certainties. The effects of this aspect have been insufficiently recognized. Restricting the use of force only to when Japan was under attack was clear-cut, easy to understand, and simple to justify. To be sure, allowing Japan from 1978 to support the U.S. military in defending the home islands was an expansion of the SDF's traditional role, but it built off of this principle in a justifiable and legally coherent manner. However, allowing for the defense or support of the U.S. or other friendly nations when Japan is not under direct attack - in "situations that influence Japanese security" - introduces ambiguity as to where and under what conditions the SDF would fight or support the militaries of other actors. The Yoshida Doctrine assuaged regional suspicions of Japan's wealth and power not only because it renounced force, but because the constitutional basis for the Doctrine gave a predictable sense of when and where Japan would operate in the region: only for self-defense, and only on its territory. The new interpretation of Article 9 muddies the predictability of direct Japanese military involvement, and it opens the door to the potentiality of additional future military roles. The changing security environment may justify the new laws, but they are not consistent with Japan's postwar strategy of restraint and reassurance.

Abe is correct that allied commitments have evolved markedly over the years to address new challenges, and in this sense his policy is just more of the same. But the new laws crossed a legal threshold and may usher in arguably the most dramatic restructuring to the U.S.-Japanese strategic role in the region since 1960. Their ambiguous wording- "threatens Japan's survival," "poses a clear danger," "situations that will have an important influence on Japan's peace and security," etc. -now obscures where and when operations are permitted.

\section{THE STRATEGIC SHIFT AND COMPROMISED REASSURANCE}

Expanded situational and geographic scope for the alliance is compounded by Abe's stated intention to defend the security foundations of the liberal order, 
which the Yoshida Doctrine did solely via economic engagement. Implicitly aligning Japan with the American-backed regional status quo in security affairs is quite different than using the alliance for national defense and to integrate Japan into the American-led economic order. If the new security laws are perceived by China to portend the emergence of Japan as a normalized military power in the absence of constitutional self-restraint, they may trigger a spiral of mutual antagonism in East Asia - precisely the situation the Yoshida Doctrine sought to avoid.

As Hughes (2015b) and other observers (e.g., Nilsson-Wright and Fujiwara 2015) have argued, the shift is already fostering mistrust. Yet by 1999, Thomas Christensen had already noted Chinese apprehensions:

The sensitivity in China to almost all changes in the Cold War version of the U.S.-Japan Alliance poses major challenges for leaders in Washington who want to shore up the alliance for the long haul by encouraging greater Japanese burden sharing, but still want the U.S. presence in Japan to be a force for reassurance in the region $(1999,51)$.

If China perceived the 1997 guidelines and the associated upgrading of Japan's role within the alliance as dangerously increasing uncertainty, it is not at all difficult to imagine how alarming the recent new laws must appear now. Remarking on the passage of the new laws, the Chinese Foreign Ministry stated:

[This] is an unprecedented move taken by post-war Japan... Japan's recent military buildup and drastic changes to its military and security policies are out of step with the trend of the times... making the international community question whether Japan is going to drop its exclusive defense policy and deviate from the path of peaceful development it has been following after WWII. ${ }^{22}$

As Japanese defense policy has incrementally whittled away at the spirit of Article 9, the security benefits of constitutional restraint and reassurance appear to no longer outweigh the security benefits of a more proactive strategic posture and a reinvigorated, less uneven alliance. When policy options were clearly constrained by the constitution, limited expansions of the SDF's role could be justified as strategic continuity. Because these constraints were fundamental to Japan's postwar strategy - the Yoshida Doctrine - this can no longer be the case.

${ }^{22}$ See Ministry of Foreign Affairs of China, "Foreign Ministry Spokesperson Hong Lei’s Remarks" (September 19, 2015). 


\section{ALLIANCE COHESION AND THE PROBLEM OF DETERRENCE}

Reducing legal constraints may inhibit credible reassurance, but does Abe's strategy employ the new constitutional interpretation in ways that generate a net increase in security? His endorsements of the new laws, such as his speech at the U.S. Congress, stress how they increase Japan's security by enhancing allied deterrence. ${ }^{23}$ This section briefly draws on IR scholarship that suggests this logic is flawed; the new laws generate no new binding, credible commitments, and although they may increase alliance cohesion, this does not preclude strengthened deterrence.

\section{HOW WOULD THE NEW LAWS ENHANCE DETERRENCE?}

Abe does not specify what kind of deterrence the new laws are intended to enhance. The IR literature distinguishes between direct and extended deterrence along one dimension and between general and immediate deterrence along another (e.g., Morgan 1983; Huth 1988; 1999). ${ }^{24}$ The U.S.-Japan military relationship has long been a one-sided defense guarantee, or U.S. extended-general deterrence against an attack on Japan. Permitting CSD in the alliance and relaxing the constraints on SDF support for the U.S. in the region, on the other hand, harnesses Japan's own latent potential to provide extended-immediate deterrence.

This is the only type of deterrence the new laws appear to affect. They do not change the credibility of Japan's direct deterrent, as they do not enhance Japan's willingness or capability to defend the homeland. Nor do they augment extended-general deterrence. U.S. commitments to defend Japanese territory are unaffected, and while Japan has shed the prohibition on defending the U.S., it has no general obligations to unconditionally support the U.S. outside Japanese territory. The 2015 guidelines also do not generate any new binding commitments nor contain a blanket pledge by Japan to defend the status quo. ${ }^{25}$

${ }^{23}$ See Office of the Prime Minister of Japan. "Towards an Alliance of Hope” (April 29, 2015).

${ }^{24}$ Direct deterrence involves national self-defense, and extended deterrence is the defense of other countries. General deterrence is a long-term commitment to security, while immediate deterrence is the employment of threats to use force when challenges are already occurring (Morgan 1983).

25 "The core of the Guidelines continues to be the steadfast commitment to Japan's peace and security. The new Guidelines detail the ways and means through which the two governments continue to strengthen their ability to fulfill that commitment." However, they "enable the Alliance to make greater contributions to international security initiatives wherever appropriate in a way consistent with Japanese laws and regulations." See Ministry of Defense of Japan, "A Stronger Alliance for a Dynamic Security Environment" (April 27, 2015). 
From their earliest incarnation, the new laws were explicitly designed to make the option of extended-immediate deterrence legally available to policymakers, so it could be invoked if necessary in "situations that will have an important influence on Japan's peace and security." ${ }^{26}$ Recently, China has been engaged in a series of territorial disputes and challenges to international law, amplifying the prospect of some future Sino-American maritime clash that may not directly involve Japanese territory but could negatively impact Japanese interests. The government claims the security legislation is defensive and reactive, enacted in response to unprecedented regional transformation. As this is a clear and present danger, the new laws are best understood as providing the option of extendedimmediate deterrence.

IR scholarship, however, provides neither a theoretical nor an empirical basis for the claim that strengthening alliances will enhance extended-immediate deterrence. Shuhei Kurizaki (forthcoming) shows that reducing constitutional constraints on the deployment of the SDF will not enhance deterrent threats. His game-theoretic analysis suggests that CSD may not be enough of a constitutional change to strengthen extended deterrence - to be credible this may require scrapping Article 9 altogether. Furthermore, the literature suggests that the presence of a military alliance, while enhancing general deterrence, does not contribute to the effectiveness of immediate deterrence once a challenge has been initiated. ${ }^{27}$

The highly asymmetrical nature of the U.S.-Japan Alliance compounds this ineffectiveness. Japan's military capability is so minute relative to America's that a potential challenger is unlikely to reassess its policy after factoring in CSD. China may be moving to revise the status quo, but in the shadow of the longstanding American commitment to the region and its great capabilities, what Japan can currently contribute is, by comparison, negligible. Thus, giving policymakers the option of assisting U.S. forces by potentially mobilizing the SDF is unlikely to change China's beliefs about the costs and benefits of continuing its assertive behavior.

\section{ALLIANCE COHESION AND ITS EFFECTS ON COERCIVE DIPLOMACY}

While the new laws are unlikely to enhance deterrence, they may strengthen

${ }^{26}$ Two of the four scenarios presented to the advisory panel involved cases of extended-immediate deterrence: a ballistic missile attack on the U.S. or a clash on the high seas. The other two involved PKOs. See Office of the Prime Minister of Japan, "Report of the Advisory Panel on Reconstruction of the Legal Basis for Security" (June 24, 2008).

${ }^{27}$ See, for example, Huth (1988; 1999) and Signorino and Tarar (2006). 
alliance cohesion by raising the efficiency of military-to-military coordination in the event of a regional crisis. Therefore the main innovation appears to be reactive, as improving response time through the new Alliance Coordination Mechanism and streamlining Japan's command structure may improve allied rapid response. Although it is not clear how enhanced military coordination affects extended-immediate deterrence, this can enhance the fighting effectiveness for the joint forces on the battlefield once immediate deterrence fails.

The IR literature on how allied and adversarial relations intersect also casts doubt on whether stronger, more cohesive alliances necessarily lead to improved security. As Glenn Snyder $(1984,1997)$ notes, allies must deal with the twin fears of abandonment in their time of need - the failure of their ally to honor the terms - and entrapment in a conflict over issues that are less salient to one side than the other. Strengthening commitments to assuage one ally's fear of abandonment will enhance the other's fear of becoming entrapped in their disputes with third parties, while mitigating this entrapment risk by loosening commitments will make the other ally more fearful of abandonment. Thomas Christensen (2011) applies this dilemma to coercive diplomacy, and argues that restructuring alliance guidelines with the aim of reducing the fear of entrapment will cause allied threats to become less credible, while tightening commitments to resolve fears of abandonment will negatively affect the credibility of assurances that the alliance is defensive. This is because demonstrating strengthened resolve can cause the adversary to enhance its own defense posture to counter the perceived threat from the allies.

The U.S.-Japan Alliance has historically been vastly asymmetrical, as Japan relinquished a measure of control over its security policy in East Asia in exchange for American security guarantees. ${ }^{28}$ Japan's main fear was entrapment in a conflict between the U.S. and Soviet Union along its northern frontiers during the Cold War. This fear was reduced after 1991. But with the rise of Chinese assertiveness and the expansion of its military capabilities in recent years, Japan's new fear is abandonment in a peripheral conflict in which the U.S. is reluctant to fight. Just as Snyder's theoretical framework suggests, Japan appears to be moving closer to the U.S. to retain its traditional place in the U.S.-led security order while American policymakers seek a more empowered Japan that can effectively handle its territorial disputes without dragging the U.S. into a war with China. ${ }^{29}$

So while the new laws may increase alliance solidarity, as the U.S. has been pushing for a more equal relationship for decades, this does not by itself translate

\footnotetext{
${ }^{28}$ On asymmetry in alliances, see Morrow (1991).

${ }^{29}$ See Nilsson-Wright and Fujiwara (2015).
} 
into enhanced deterrence or Japanese security. Christensen (2011) suggests that moves to make allied relations more equitable and durable for the long term will reduce the short-term credibility of assurances. Reshaping the alliance into a more symmetric relationship undermines its secondary function as a mechanism for restraining Japan in the eyes of its neighbors; and repositioning Japan's role in the alliance from a reactive to a proactive partner may also decrease Japan's security by prompting China to respond to what appears to be a strategy of containment.

\section{WHY THE NEW LAWS COULD HEIGHTEN THE SECURITY DILEMMA IN EAST ASIA}

Japan has altered its postwar strategy because rebuking U.S. pressure and remaining aloof from power politics appears, from the government's perspective, no longer strategically beneficial in light of the shifting security environment. Japan may no longer be completely passing the buck, as Lind argued in 2004, but rather is slowly adjusting to conditions that require balancing Chinese influence in East Asia. If she is correct that Japan only raises its defense posture when it perceives that U.S. commitment is lacking, the new laws and new strategy indicates that the Japanese government believes they may be forced to take a more proactive posture in the region because the U.S. can no longer - or in the future, will be unable to - guarantee stability and the regional order on its own. This may explain why Abe is willing to sacrifice some measure of reassurance in order to more credibly signal Japanese resolve to stand with the U.S. against long-term challenges. In this sense, although Japan's extended-immediate deterrence option may not immediately increase national security, the new laws signal that Japan is resolute about defending the status quo.

However, this strategy effectively redefines the scope of Japanese defense interests as more expansive than defending the home islands, and therefore should have an effect on the security dilemma in East Asia. This highly conditional new commitment might sow the seeds for defensive Chinese countermeasures or probing actions on interests peripheral to the U.S. that will further escalate tensions. In this section, we provide a brief overview of the security dilemma and its application to international politics in East Asia. ${ }^{30}$

$3^{30}$ This section draws from and builds upon Capistrano (2016, ch. 4). 


\section{THE POST-COLD WAR SINO-JAPANESE SECURITY DILEMMA}

The security dilemma is a well-known problem for security-seeking states that can benefit from mutual cooperation and restraint but end up both defecting because "many of the means by which a state tries to increase its security decrease the security of others" (Jervis 1978, 169). When there is insufficient trust between states, building arms or militarizing strategic territory - though intended to defensively increase security - can be perceived as offensively-oriented by the other state, prompting them to rearm or mobilize in response. This causes a chain reaction, or spiral of mistrust, that will be not only costly but leave both sides with less security than if they had cooperated to enforce mutual restraint. ${ }^{11}$ Despite their security-seeking preferences, states cannot trust each other enough to coordinate on mutual cooperation because they both expect to be taken advantage of by the adversary. This outcome would be worse than suffering the costs of mutual defection. Raising strategic trust and maintaining credible commitments to restraint can ameliorate this fear of having one's cooperation exploited, leading the states to move away from their costly competition for security. ${ }^{32}$

Aaron Friedberg (1993) argued that the collapse of the Soviet Union made the security environment in East Asia "ripe for rivalry." Christensen (1999) noted that interviews he conducted with Chinese security analysts and military officers revealed a "fear that Japan could again become a great military power in the first quarter of the twenty-first century. Such a Japan, they believe, would likely be more independent of U.S. control and generally more assertive in international affairs." He noted that spirals of mistrust might accompany a more symmetric U.S.-Japan Alliance. The shifting balance of power and changing regional influence since 1999 has favored China over Japan, setting the context for the gradual increase in alliance symmetry.

However, we argue that this expectation of heightened strategic mistrust has been confirmed for at least two other reasons. First, the Senkaku/Diaoyu territorial dispute has deteriorated bilateral relations, and China and Japan both regard each other as the challenger to the status quo. Second, this has occurred alongside the slow expansion of SDF roles within the alliance and their permissible geographic scope. Alongside the rise of China, the combination of these two factors accelerated recent Sino-Japanese strategic competition against what each side sees as revisionist behavior.

\footnotetext{
${ }^{31}$ See Glaser (1997).

${ }^{32}$ On trust and the security dilemma, see Kydd (2005).
} 


\section{THE STATUS QUO TO WHOM? THE SENKAKU ISLANDS DISPUTE AND STRATEGIC MISTRUST}

Territorial disputes are genuine conflicts of interest, and therefore security dilemma dynamics would seem not to apply. Yet the severity of the larger SinoJapanese security dilemma is conditioned on perceptions of strategic intent, and each side takes the other's behavior in the dispute as confirmation that it is revisionist. This subsection briefly examines the influence of the Senkaku dispute on perceptions of the other side as a status quo actor.

As Liff and Ikenberry $\left(2014,75^{-76}, 86\right)$ recently noted, "A major, if not the primary, driver of Japan's efforts to enhance its military capabilities in recent years appears to be a perceived growing threat from China... An increasingly salient factor in Japanese defense planners' calculations is the manner in which China is asserting its claim to the Senkaku/Diaoyu Islands in the East China Sea." They further identify uncertainty over China's strategic intentions as the main reason for the heightened security dilemma in Asia. Incursions into Japanese waters have increased since the end of the Cold War, prompting coast guard responses and setting the stage for debates surrounding Japan's security.

From China's perspective, however, Japan is the revisionist. Tokyo nationalized the islands unilaterally from their private Japanese owner in September 2012. This action followed earlier attempts by Japan to solidify its position in the dispute, and confirmed to China that it was in the process of rolling back commitments of restraint. In 1996, Japanese activists had constructed a lighthouse on one of the islands, in 2002, the government tried to lease them from their private owner, and in 2005 the lighthouse was formally recognized as under state control. China responded with outrage that all these actions were illegal and invalid. 33 The 'trawler incident' in $\mathbf{2 0 1 0}$ - when a Chinese fishing vessel collided with a Japanese Coast Guard ship - marked the beginning of increased incursions into the area by activist groups and government ships from both sides. Ultimately, the Japanese government decided to purchase the islands in 2012 to deter right-leaning domestic groups. China strongly objected.

The dispute has further escalated into an at-times dangerous military standoff. Following nationalization, Japan has acted in light of perceived Chinese assertiveness - not only in the Senkaku dispute, but in the South China Sea as well. In a 2013 white paper, the Japanese government alludes to how China's actions in territorial disputes color how they see Chinese intentions. It notes the uncertainty surrounding China's rising military power due to the dispute:

33 See Weiss (2014, ch. 5-6). 


\begin{abstract}
China has not clarified the current status and future vision of its military modernization initiatives, [...] this could potentially lead to a sense of distrust and misunderstanding by other countries. Furthermore, China has been rapidly expanding and intensifying its maritime activities. In particular, in the waters and airspace around Japan, it has engaged in dangerous acts that could give rise to a contingency situation, [...] Coupled with the lack of transparency in its military and security affairs, these moves by China are a matter of concern for Japan and other countries in the region and the international community. 34
\end{abstract}

Meanwhile, in China, the abrupt nationalization of the islands seems to precipitate future Japanese military re-assertiveness. In Beijing, the government views its response as justifiable following Japanese revisionism. It nevertheless uses anti-Japanese sentiment to build patriotism, suppressing and allowing it depending on state policy. 35 In a public statement following nationalization, the Chinese Foreign Ministry stated "[Japan] stirred up tension when 'purchasing and nationalizing islands'... [and] constitutes a threat to the peace and stability of the AsiaPacific region." ${ }^{6}$ China can make the argument that Japan is overturning the status quo in Asia through such re-assertive behavior. Foreign Minister Zhang Zhijun declared, “There has been a serious backtracking in Japan's position... It has taken a series of unilateral moves to infringe upon China's rights and provoke matters... The illegal 'island purchase' by Japan thoroughly undermined the consensus reached between the two sides and effected a fundamental change in the situation."37

This disagreement on the nature of the status quo - and who the revisionist is is reinforcing the security dilemma's spiral of mistrust. Japan does not concede that a dispute actually exists. Unless both sides can agree on a status quo it will be impossible for them to coordinate to enforce it. For decades, stability in the island dispute was achieved only through mutual restraint and bargaining delays. This delay was not costly enough to either side when compared to the benefits of keeping the issue on the sidelines of their wider relationship. ${ }^{38}$ In the process, however, mistrust has blossomed because the dispute has consistently prevented

\footnotetext{
${ }^{34}$ See Ministry of Defense of Japan, "Defense of Japan 2013" (white paper, 2013), I-2.

35 Weiss $(2014,1)$ notes, "Anti-Japanese demonstrations were repressed throughout the $1990 \mathrm{~s}$ and late 2000 sut erupted in 1985, 2005, 2010, and 2012."

${ }^{36}$ See Ministry of Foreign Affairs of China, "The Diaoyu Islands: The Owner and the Thief" (October 22, 2012).

${ }^{37}$ See Ministry of Foreign Affairs of China, "Vice Foreign Minister Zhang Zhijun Gave Briefing to Chinese and Foreign Journalists on the Diaoyu Dao Issue" (October 27, 2012).

${ }^{38}$ See Fravel (2010).
} 
the dispelling of doubts over strategic intentions.

The security dilemma is most pronounced when both sides see their actions as defensive and perceives the other's as offensive. Strategic mistrust of China is inducing a security-seeking response on the part of Japan - the new laws - that will only further exacerbate the security dilemma. China's assertiveness in resisting Japan's normalization of the islands has given Abe domestic political capital to pursue changes once inconceivable in the years before 2012. It has also prompted other states with territorial disputes, such as the Philippines, to see Japan as a potential partner and given Japan a strategic incentive to further align with the U.S.-led regional order. Finally, in 2013, the U.S. acknowledged for the first time that the islands were definitively covered under Article 5 of the alliance. The longstanding U.S. policy of refusing to take sides in the dispute while warning both Japan and China against trying to change the status quo by force was undermined to facilitate this defense commitment.

\section{SIGNALING RESOLVE OR REVISIONIST INTENT? PERCEPTIONS OF THE U.S.-JAPAN ALLIANCE}

The commitment to defend the Senkakus is part of a broader regional strategy aiming to sustain the maritime status quo against Chinese assertiveness. Japan had long sought a commitment to defend the Senkakus, but only recently did they tie this dispute to questions of regional order. The 2013 National Security Strategy noted:

China has taken actions that can be regarded as attempts to change the status quo by coercion based on their own assertions, which are incompatible with the existing order of international law in the maritime and aerial domains. 39

Both allies connected the territorial dispute to larger strategic issues presented by a rising China, particularly in regard to the South China Sea disputes. The latest decision to revise the guidelines reflects this convergence of interests..$^{\circ} \mathrm{In}$ other words, a bilateral dispute has become folded into broader challenges to the status quo, providing the U.S. with an opportunity to nudge Japan towards assuming greater responsibility for the regional order, and creating conditions that make the U.S. want to clarify its commitment to stand firm in a conflict over the Senkakus.

\footnotetext{
${ }^{39}$ See Office of the Prime Minister of Japan, "National Security Strategy" (December 17, 2013).

$4^{\circ 0}$ See US Department of Defense, “Quadrennial Defense Review 2014” (March 4, 2014).
} 
As we noted earlier, the new laws build allied cohesion. Recent developments in East Asia have offered both incentives and internal rewards to bring the allies closer together. Externally, policymakers in Tokyo and Washington believe these changes in the alliance will signal resolve to an increasingly assertive China, but this compounds the disagreement over the status quo in the East China Sea (Singh 2014; Capistrano 2016). The motivation for the 2015 guidelines revision was the effect of China's rise and assertiveness on the security environment. But if China believes its own behavior is a security-seeking response to Japanese reassertiveness, the guidelines and new laws will be regarded as more threatening than intended. Below, we survey Chinese perceptions of previous changes in the alliance guidelines that were undertaken to adjust to shifting regional security needs.

The first guidelines in 1978 were tailor-made for the challenges posed by the Soviet naval buildup in Northeast Asia. These guidelines covered three areas: deterring threats; defending Japan during an attack; and cooperation with the U.S. during "situations in the Far East outside of Japan which will have an important influence on the security of Japan."41 However, as James Przystup $(2015,6)$ notes, this only amounted to an "agree[ment] to conduct studies on the nature and dimension of assistance that Japan, in accordance with its 'relevant laws and regulations,' could provide to the United States." In practice, these laws and regulations severely limited any possibility of Japanese assistance in regional security, and as a result China did not see them as particularly threatening. Moreover, at the time the bulk of SDF forces were positioned to defend against a Soviet invasion from the north.

China initially feared that the alliance would break down in the absence of the Soviet threat, and security analysts in Beijing were worried about the potential for Japanese remilitarization that would surely follow. The end of the Cold War prompted alliance managers to rewrite these guidelines in the 1990 s instead. Yet after the 1996 joint communique from President Clinton and Prime Minister Hashimoto stating their intention to revitalize the alliance to provide security for the Asia-Pacific region, Chinese perceptions changed. They now were frightened by a more cohesive alliance posture with greater roles for Japan in regional security (Christensen 1999, 60-62).

Chinese suspicions over the 'Asia-Pacific' geographic scope were understood, and the 1997 guidelines opted to change this to a situational description. ${ }^{2}$

\footnotetext{
${ }^{41}$ See Ministry of Defense of Japan, “The Guidelines for Japan-U.S. Defense Cooperation” (November 27, 1978).

${ }^{42}$ As mentioned above, this was "situations in areas surrounding Japan."
} 
Nevertheless, the timing of the communique - just one month after the Third Taiwan Strait Crisis had seen the U.S. deploy two aircraft carriers as a signal of resolve - raised the question of what role, if any, Japan would play in future U.S. coercive diplomacy directed towards China. Whether or not the new guidelines meant Taiwan and the South China Sea could be defended by the alliance remained unclear. Alastair Iain Johnston $(2003,43)$ has noted, “China's diplomacy toward the U.S.-Japan Alliance... has been largely aimed at extracting some kind of credible commitment - so far unsuccessful - that the alliance not be used to defend Taiwan in a conflict with the PRC." He argues further that China wanted a return to the pre-1996 alliance, restoring its postwar function of restraining Japan by providing one-sided security guarantees.

Apprehensions in China regarding the alliance's scope are likely to be confirmed by the new laws. At the same time, it is still unclear which situations would be determined to have enough of an influence on Japan's security to warrant SDF involvement. Allowing for CSD if the U.S. is under attack appears to expand Japan's military role in the alliance, raises questions about the future regional influence of the alliance, and, though it might improve their ability to signal resolve on regional security issues, ultimately hinders the allies from doing so without prompting China to reflexively and defensively respond. This could make the region more secure, but it could also bind the alliance to defend issues that only have a minor peripheral impact on Japanese security. 43

The positive effect of enhancing allied cohesion must be evaluated in light of severe Sino-Japanese mistrust. The 2015 guidelines are likely to confirm to Chinese policymakers that the 1997 guidelines were only the first step in unleashing Japan's military potential to support U.S. foreign policy. Signals of resolve under this framework will have the probable effect of making Japan appear increasingly revisionist, in the sense that they are directed at freezing a status quo that China believes infringes on its sovereignty. In fact, any change in the alliance has historically been seen as a revisionist shift in the status quo balance of power. The Sino-Japanese security dilemma is, in this way, unique. Rather than building arms to ensure its security and demonstrate its commitments, Japan has opted to reduce the restraining function of its constitutional interpretation. But Japan should be weary of the impact this will have on the security of its neighbors, particularly China. Reducing constraints to signal resolve has a similar effect as building new military capabilities in an environment marked by strategic mistrust: increasing security in this way also lowers the security of others.

${ }^{43}$ See Capistrano (2016). 


\section{CONCLUSION}

This article made three main claims. First, the longstanding reassurance function of the Japanese constitution has been undermined by the new, ambiguous interpretation of Article 9. Second, new commitments to deter an attack on Japan or its interests have not been generated by the new laws and preexisting commitments have not been markedly enhanced. Third, the new laws may enhance allied cohesion and Japan's ability to participate in regional security operations. But in light of strategic mistrust intensified by the Senkaku dispute and Chinese suspicions about past expansions of Japan's influence in the alliance or regional security affairs, in coming years, the new laws are just as likely to foster insecurity for Japan.

The future implications of the new laws for Chinese security will depend on whether Abe or his successors continue to twist the bottle cap and further reduce constitutional constraints or if the U.S. judges that a normalized Japan is ready to hatch from the eggshell. Right now, alongside China's rise in power, it is the uncertainty fostered by a strategic shift away from the Yoshida Doctrine and the Cold War-era U.S.-Japan Alliance that is most destabilizing, and the potential for an exacerbated security dilemma deserves greater attention. As Japan searches for security in a shifting strategic environment, policymakers in Tokyo, Washington, and even Beijing should be more vigilant than ever before to avoid spirals of mistrust and remain aware of how their signals can inadvertently trigger security dilemma dynamics.

\section{REFERENCES}

Armitage, Richard and Joseph Nye. 2007. The U.S.-Japan Alliance: Getting Asia Right through 202O. Washington, DC: Center for Strategic and International Studies.

Calder, Kent. 2009. Pacific Alliance: Reviving U.S.-Japan Relations. New Haven: Yale University Press.

Capistrano, Andrew. 2016. "Coercion under the Security Dilemma." M.A. Thesis, Waseda University.

Christensen, Thomas. 1999. "China, the U.S.-Japan Alliance, and the Security

Dilemma in East Asia." International Security 23(4), 49-80. . 2011. Worse than a Monolith. Princeton: Princeton University Press.

Fearon, James. 1994. "Signaling versus the Balance of Power and Interests: An Empirical Test of a Crisis Bargaining Model." Journal of Conflict Resolution 
38(2), 236-269.

Fravel, M. Taylor. 2010. "Explaining Stability in the Senkaku (Diaoyu) Dispute." In Gerald Curtis, RyoseiKokubun, and Wang Jisi, eds., Getting the Triangle Straight: Managing China-Japan-US Relations, Washington, DC: The Brookings Institution Press, 144-164.

Friedberg, Aaron. 1993. "Ripe for Rivalry: Prospects for Peace in a Multipolar Asia." International Security 18(3), 5-33.

Gartzke, Erik, and Koji Kagotani. 2015. "Trust in Tripwires: Deployments, Costly Signaling, and Extended General Deterrence.” Manuscript, University of California, San Diego, and Osaka University of Economics.

Glaser, Charles. 1997. "The Security Dilemma Revisited." World Politics 50(1), 171-201.

Hughes, Christopher. 2004. Japan's Re-emergence as a 'Normal' Military Power. London: IISS Press.

. 2015a. “An ‘Abe Doctrine as Japan’s Grand Strategy: New Dynamism or Dead-End?” The Asia-Pacific Journal. Accessed at http://apjjf.org/Christopher-W--Hughes/4832/article.pdf (March 13, 2016). . 2015b. Japan's Foreign and Security Policy under the Abe Doctrine: New Dynamism or Dead End? New York: Palgrave Macmillan.

Huth, Paul. 1988. "Extended Deterrence and the Outbreak of War." American Political Science Review 82(2), 423-443.

. 1999. "Deterrence and International Conflict: Empirical Findings and Theoretical Debates." Annual Review of Political Science 2, 25-48.

Jervis, Robert. 1978. "Cooperation under the Security Dilemma." World Politics 30(2), 167-214.

Johnston, Alastair Iain. 2003. "Is China a Status Quo Power?" International Security 27(4), 5-56.

Kurizaki, Shuhei. Forthcoming. "A Signaling Game of Collective Self-Defense in the U.S.-Japan Alliance.” In Motoshi Suzuki and Akira Okada, eds., Games of International Conflict and Cooperation in Asia, New York: Springer.

Kydd, Andrew. 2005. Trust and Mistrust in International Relations. Princeton: Princeton University Press.

Leeds, Brett. 2003. "Do Alliances Deter Aggression? The Influence of Military Alliances on the Initiation of Militarized Interstate Disputes." American Journal of Political Science 47(3), 427-439.

Liff, Adam and G. John Ikenberry. 2014. "Racing toward Tragedy? China's Rise, Military Competition in the Asia Pacific, and the Security Dilemma." International Security 39(2), 52-91. 
Lind, Jennifer. 2004. "Pacifism or Passing the Buck? Testing Theories of Japanese Security Policy.” International Security 29(1), 92-121.

Liu, Jiangyong. 1998. "New Trends in Sino-U.S.-Japan Relations." Contemporary International Relations 8(7), 1-13.

Ministry of Defense of Japan. 1978. "The Guidelines for Japan-U.S. Defense Cooperation.” November 27. Accessed at http://www.mod.go.jp/e/ d_act/anpo/pdf/19781127.pdf (March 13, 2016). . 1997. "The Guidelines for Japan-U.S. Defense Cooperation.” September 23. Accessed at http://www.mod.go.jp/e/d_act/anpo/pdf/ 19970923.pdf (March 13, 2016). . 2004. "National Defense Program Guidelines." December 10. Accessed at http://www.mod.go.jp/e/d_act/d_policy/pdf/national_guidelines.pdf (March 13, 2016).

. 2013. "Defense of Japan 2013" (white paper), I-2. Accessed at http://www.mod.go.jp/e/publ/w_paper/pdf/2013/o7_Part1_Chaptero _Sec2.pdf (March 13, 2016).

. 2015. "Defense of Japan 2015." II-1-2 and II-1-3. Accessed at http://www.mod.go.jp/e/publ/w_paper/2015.html (March 13, 2016). . 2015. "A Stronger Alliance for a Dynamic Security Environment: The New Guidelines for Japan-U.S. Defense Cooperation (Joint Statement)." Accessed at http://www.mod.go.jp/e/d_act/anpo/pdf/js20150427e.pdf (March 13, 2016).

Ministry of Foreign Affairs of China. 2012. "The Diaoyu Islands: The Owner and the Thief." October 22. Accessed at http://www.fmprc.gov.cn/ mfa_eng/topics_665678/diaodao_665718/t981211.shtml (March 13, 2016).

. 2012. "Vice Foreign Minister Zhang Zhijun Gave Briefing to Chinese and Foreign Journalists on the Diaoyu Dao Issue." October 27. Accessed at http://www.fmprc.gov.cn/mfa_eng/topics_665678/diaodao_665718/t 983015.shtml (March 13, 2016).

. 2015. "Foreign Ministry Spokesperson Hong Lei's Remarks on Japanese Diet's Approval of New Security Legislation.” September 19. Accessed at http://www.fmprc.gov.cn/mfa_eng/xwfw_665399/s2510_665401/253 5_665405/t1298235.shtml (March 13, 2016).

Ministry of Foreign Affairs of Japan. 2015. "The Guidelines for Japan-U.S. Defense Cooperation.” April 27. Accessed at http://www.mofa.go.jp/ files/000078188.pdf (December 15, 2015). . 2015. “Japan's Legislation for Peace and Security.” November. Accessed at http://www.mofa.go.jp/files/oooo80671.pdf (December 15, 2015). 
Morgan, Patrick. 1983. Deterrence: A Conceptual Analysis. New York: Sage Publications.

Morrow, James. 1991. "Alliances and Asymmetry: An Alternative to the Capability Aggregation Model of Alliances," American Journal of Political Science 31(4), 904-933.

Murata, Koji. 2000. "Do the New Guidelines Make the Japan-U.S. Alliance More Effective?” In Masashi Nishihara, ed., The Japan-U.S. Alliance, Tokyo: Japan Center for International Exchange, 19-38.

Nilsson-Wright, John and Kiichi Fujiwara. 2015. Japan's Abe Administration: Steering a Course between Pragmatism and Conservatism. London: Chatham House.

Office of the Prime Minister of Japan. 2008. "Report of the Advisory Panel on Reconstruction of the Legal Basis for Security." June 24. Accessed at http://www.kantei.go.jp/jp/singi/anzenhosyou/report.pdf (March 13, 2016).

. 2013. "The Bounty on the Open Seas: Five New Principles for Japanese Diplomacy." January 18. Accessed at http://japan.kantei.go.jp/96_ abe/statement/201301/18speech_e.html (March 13, 2016).

. 2013. "National Security Strategy." December 17. Accessed at http://japan.kantei.go.jp/96_abe/documents/2013/__icsFiles/afieldfile/2013/12/17/NSS.pdf (March 13, 2016). . 2014. "Report of the Advisory Panel on Reconstruction of the Legal Basis for Security." May 15. Accessed at http://www.kantei.go.jp/jp/singi/ anzenhosyou2/dai7/houkoku_en.pdf (March 13, 2016).

. 2014. "Cabinet Decision on Development of Seamless Legislation to Ensure Japan's Survival and Protect its People." July 1. Accessed at http://japan.kantei.go.jp/96_abe/decisions/2014/__icsFiles/afieldfile/2014/07/03/anpohosei_eng.pdf (March 13, 2016).

. 2015. "Press Conference by Prime Minister Shinzo Abe Following the Cabinet Decision on the 'Legislation for Peace and Security." May 14. Accessed athttp://japan.kantei.go.jp/97_abe/statement/201505/ 0514kaiken.html(March 13, 2016).

. 2015. "Towards an Alliance of Hope." April 29. Accessed athttp://japan.kantei.go.jp/97_abe/statement/201504/uscongress.htm 1 (March 13, 2016).

Potter, David. 2015. "Evolution of Japan's Postwar Foreign Policy." Manuscript, Nanzan University.

Przystup, James. 2015. "The U.S.-Japan Alliance: Review of the Guidelines for Defense Cooperation.” Strategic Perspectives 18 Institute for National 
Strategic Studies, National Defense University.

Samuels, Richard. 2007. “New Fighting Power!' Japan's Growing Maritime Capabilities and East Asian Security.” International Security 32(3), 84112.

Schelling, Thomas. 1966. Arms and Influence. New Haven: Yale University Press. Singh, Bhubhindar. 2014. "Obama, the Senkaku/Diaoyu islands, and the USJapan Security Treaty.” PacNet 36A. Accessed at http://csis.org/files/ publication/Pac1436A.pdf (March 13, 2016).

Signorino, Curtis and Ahmer Tarar. 2006. "A Unified Theory and Test of Extended Immediate Deterrence.” American Journal of Political Science $50(3), 586-605$.

Snyder, Glenn. 1984. "The Security Dilemma in Alliance Politics." World Politics 36(4), 461-495. . 1997. Alliance Politics. Ithaca: Cornell University Press.

Takahashi, Sugio. 2013. Upgrading the U.S.-Japan Alliance Guidelines: Toward a new Phase of Operational Cooperation. Arlington, VA: Project 2049 Institute. Accessed at http://project2049.net/documents/japan_us_ defense_guidelines_takahashi.pdf (March 13, 2016).

U.S. Department of Defense. 2014. "Quadrennial Defense Review 2014." March 4. Accessed at http://archive.defense.gov/pubs/2014_Quadrennial_ Defense_Review.pdf (March 13, 2016).

U.S. Department of State. 2005."U.S.-Japan Alliance: Transformation and Realignment for the Future." October 29. Accessed at http://20012009.state.gov/documents/organization/55886.pdf (March 13, 2016).

Weiss, Jessica Chen. 2014. Powerful Patriots: Nationalist Protest in China's Foreign Relations. New York: Oxford University Press. 